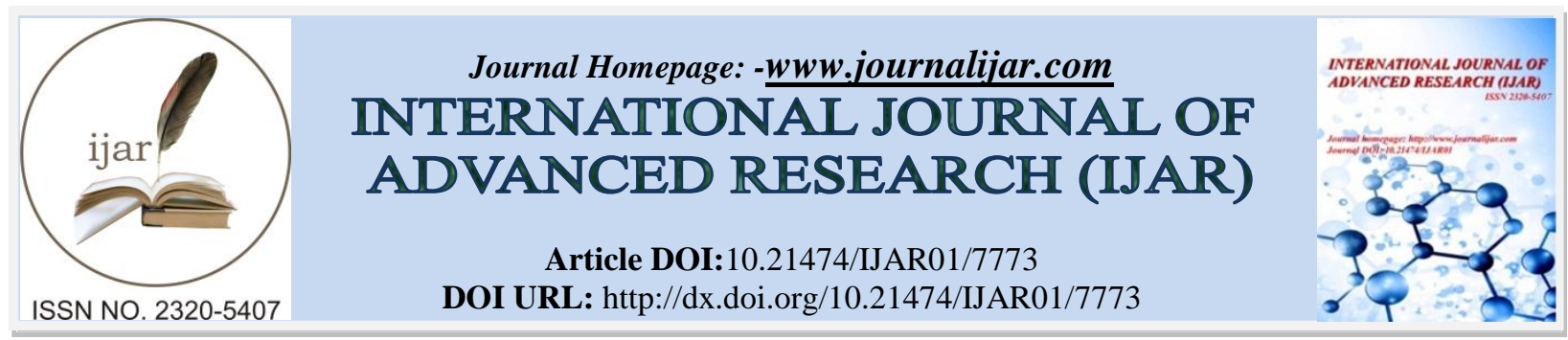

RESEARCH ARTICLE

\title{
OPTIMIZATION OF INDONESIAN NATIONAL ARMY (TNI) UNITED IN BUILDING VILLAGE (TMMD) IMPLEMENTATION IN ORDER TO REALIZE COMMUNITY SOCIAL RESILIENCE.
}

Fadli Mulyono, Setyo Widagdo and Mukhammad Soleh.

1. Master student of brawijaya university.

2. Postgraduate Lecturer Of Brawijaya University.

3. Postgraduate Lecturer Of Wisnu Wardhana University.

\section{Manuscript Info}

Manuscript History

Received: 25 July 2018

Final Accepted: 31 August 2018

Published: September 2018

\section{Abstract}

The research purposes of this study are as follows: To analyze optimization and implementation, obstacles, and finding optimization and implementation models of Indonesian National Army (TNI) United In Building Village (TMMD) to 101 Year of 2018. This research was conducted in Penatarsewu Village, Tanggulangin District, Sidoarjo Regency, while the research time was carried out for 3 months, from March to May 2018.

This research uses descriptive method with quantitative approach. This method was chosen to obtain a clear and detailed picture related to the research problems and phenomena studied. Data collection techniques used questionnaires, documentation, and interviews. This study directly refers to data from informants such as the Head of Village Community Empowerment, Women's Empowerment and Child Protection, $K B$ (Family Planning) of Sidoarjo Regency and the Military District of Military Command 0816 Sidoarjo and data obtained from the Head of the Penatarsewu Village District. Tanggulangin and Kodim Administrative Officer 0816, Sidoarjo.

The results showed that: Optimizing and implementing the Indonesian National Army (TNI) United In Building Village (TMMD) program to 101 year of 2018 requires a policy to start the development of collaboration between agencies starting from the objectives, targets, subjects, objects, methods ranging from physical development, economic, socio-cultural, non-physical development carried out through increasing awareness of state defense, community skills, Entrepreneur debriefing, social culture, education and legal literacy. In dealing with various obstacles must optimize development both from inside and outside. The model of optimization and implementation of targeting must be well planned, starting from the planning, preparation, implementation and scaling up stages so that the target can touch the needs of the community and in accordance with the priority scale of needs. 


\section{Introduction:- \\ Background:-}

The challenge for Indonesia's national defense is very large. So, in the modern era in Indonesia, it is the government that holds the greatest responsibility in defense area empowerment management. The Indonesian government adheres to the implementation of national defense through three mechanisms of activity. According to Permenhan (Ministry of defence Regulation) No. 40/2011, the three are: preparing the potential of national resources to become a defense force prepared early, the involvement of the community in the national defense through the preparation of the implementation of compulsory military basic training, the projected involvement of the community in the national defense for OMP (War Military Operations) which is carried out through data collection and fostering the people.

Observing global, regional and national dynamics can be seen as a threat to the sovereignty and integrity of the Unitary Republic of Indonesia, including the threat of ideology such as the erosion of insight and national ethos, political threats such as weakening state authority and an almost unlimited increase in the degree of freedom. In addition, the thickening of feudalism was marked by strong efforts to hunt for power, class fanaticism and government instability (as a result of multiparty systems and direct electoral systems). The threat on the economic side includes the capitalist economic system (neoliberalism) which causes the national economy to be dominated by the power of foreign capital, and dependence on foreign economic assistance. Socio-cultural threats such as increasingly widespread understanding of materialism, consumerism, hedonism, permisivism and individualism, legal threats such as corruption, tax evasion, and indications of increasingly widespread drug trafficking. Threats also come from the side of religion, such as attempts to compete with religious and internal religious communities so as to disturb the harmony of religious life. Likewise the threat of defense and security, such as separatism, terrorism, the problem of annexation and encroachment of border areas, and control by neighboring countries.

Therefore, in enhancing a good TNI-People unity system, United of TNI-People is an interaction between a solid unity and unity between the TNI and the people to create dynamic cooperation for the betterment of society. The TNI-People unity is often interpreted as a people's effort to assist the TNI in opposing the invaders, either participating as troops on the battlefield, or only participating in helping in the form of providing food, medicine, or hiding places for TNI soldiers. Whereas in the post-war era, the TNI-People Unity was then interpreted as an effort by the TNI to collaborate with the community in development efforts.

Indonesian National Army (TNI) United In Building Village (TMMD) is one of the forms of Operation of TNI loyalty which is a cross-sectorial cooperation program between the TNI, Non-Ministry Ministries / Local Government Agencies and other national components, which are carried out in an integrated and sustainable manner in an effort to help accelerate development in the region -area. Development is prioritized in poor / underdeveloped, isolated / remote areas in order to empower defense areas and improve the welfare of the community, creating resilient regional resilience and strengthening national unity. The implementation of Indonesian National Army (TNI) United In Building Village (TMMD) was carried out to 101 year 2018 in the area of Kodim 0816 Sidoarjo which is located in Penatarsewu Village, Tanggulangin, Sidoarjo which has an area of $+186,840 \mathrm{Ha}$ with a population of 4,394 people, is a category of rural areas which also includes underdeveloped areas in the development of regional development in the economy and the results of the implementation of Indonesian National Army (TNI) United In Building Village (TMMD) program to 101 year 2018 in Sidoarjo Regency is a supporter of the regional government in enhancing the program of equal distribution of regional development, especially in areas that are lacking in getting development attention so that it is expected to help improve the welfare of the people who are guided by the Unity of the TNI and the People. Therefore the 101st TMMD year of 2018 can be carried out according to the expected goals and objectives.

\section{Research purposes:-}

Based on the above background, the research objectives are as follows;

1. Analyzing Optimization and Implementation of Indonesian National Army (TNI) United In Building Village (TMMD) to 101 Year of 2018 in order to improve social resilience of the community;

2. Analyzing barriers to optimization and implementation of Indonesian National Army (TNI) United In Building Village (TMMD) to 101 Year of 2018; and

3. Finding the optimization model and Implementation of Indonesian National Army (TNI) United In Building Village (TMMD) to 101 Year of 2018. 


\section{Research Methods:- \\ Time and Location of Research:-}

This research was conducted in Penatarsewu Village, Tanggulangin District, Sidoarjo Regency, while the research time was carried out for 3 months, from March to May 2018.

\section{Research methods:-}

This study uses descriptive method with a quantitative approach or called descriptive statistics. In this study the researchers want to describe the data about Optimizing the Implementation of the Indonesian National Army (TNI) United In Building Village (TMMD) in the Framework of Realizing Community Social Resilience.

\section{Sampling technique:-}

The sampling technique used in this study is the Non-random sampling technique, namely the Head of Village Community Empowerment, Women's Empowerment and Child Protection, Family Planning Organization of Sidoarjo Regency, Drs. Ec. Ali Imron, MM, and Sidoarjo Kodim Territorial Territorial Officer, Captain Arh Bambang Suryono and Penatarsewu Village Chief, Tanggulangin Mr. Kholik and Administrative Officer of the Kodim 0816 Sidoarjo Territorial Staff Serma Sutrisno.

\section{Data Retrieval Techniques:-}

Data collection techniques used in this study were questionnaires, documentation and interviews.

Data analysis technique:-

This study uses qualitative statistical techniques while to analyze using qualitative analysis and quantitative analysis.

\section{Research Result And Discussion:-} Implementation of the TMMD Kodim 0816 Sidoarjo:-

The results of an interview with Sergeant Sutrisno as the Kodim 0816 Territorial Administrative Officer Sidarjo said that the implementation of the TMMD program carried out by the Kodim 0816 Sidoarjo went to 101 TA. 2018 takes the theme "TNI Manunggal Rakyat Building Character and Independence of the Nation". The time for the Pre TMMD to be held on March 1 until March 30, 2018 for 30 days before the TMMD starts, while the TMMD is held on April 4, 2018 to May 3, 2018 for 30 days.

Physical targets in this TMMD are (1) Principal Objectives consisting of Making a connecting road between Penatarsewu village to Banjarasri village RT $05 \mathrm{RW} 01$ with a length of $500 \mathrm{M}$ and Width $3 \mathrm{M}$ whose work is under the supervision of the Office of Public Works and Spatial Planning (PUPR), maintenance of the drainage channel of Penatarsewu Village RT 05 RW 01 with a length of $1,800 \mathrm{M}$ and width 4 whose work is under the supervision of the PUPR Office of the Sidoarjo Regency, rehap and Pavingization of SDN 1 Penatarsewu RT 10 RW 02 with a volume of $49 \mathrm{M}^{3}$ whose work is under the supervision of the District Education and Culture Office, Sidoarjo; and maintenance of $1,000 \mathrm{M}^{2} \mathrm{RT} 01 \mathrm{RW} 01$ clean water facilities whose work is under the supervision of Sidoarjo Regency; (2) Additional targets consisting of the construction of the RT $07 / 08 \mathrm{RW} 02$ with $280 \mathrm{M}^{3}$ of work under supervision by the Housing and Settlement Office District of Sidoarjo and construction of healthy latrines Penatarsewu as many as 27 units whose work is under the supervision of the Housing and Settlement Office District of Sidoarjo (3) Non-Physical Target consists of counseling administrators of administrative and civil registration documents, birth certificate administration, Agricultural Hand sprayer Assistance, Counseling / coaching related to Regional legislation, trash processing training, Aid for garbage counting machines, Motorbike Assistance garbage transporter, freshwater / brackish fish cultivation training, fanani shrimp seed assistance, pilot library assistance, joint sports and river awareness socialization; (3) Over Achievement Goals consist of 3 units of renovation of Unworthy Houses (RTLH) from Mitra Kodim 0816 Sidoarjo Self-supporting Budget, 1 Unit of Family Latrine latrines from Mitra Kodim 0816 Sidoarjo Self-supporting budget, mobile library services to elementary school, kindergarten and MI and madrasa by using the facilities of SIMOKOS motorcycle (Social Communication Motor Information Facility) Babinsa, Watching together with the screening of the film of the Commander in Chief of Sudirman and Merah Putih indeed, the provision of nine basic necessities for the underprivileged as many as 100 Packages, Aid 250 Holy Qur'an, Book and pencil assistance and colored markers for students Penatarsewu as many as 200 pieces, 32 days free medical services at TMMD Command Post to 101 TA. 2018, Free cataract eye surgery, posyandu and elderly services as well as KB IUD, implants, pills and sutures, blood donors and procurement of bazaars and cheap markets. 
The phasing of the activities of Indonesian National Army (TNI) United In Building Village (TMMD) activities to 101 year of 2018 includes the planning stage, preparation phase, implementation phase, assessment / report stage and evaluation.

Optimization and Implementation of the Indonesian National Army (TNI) United In Building Village (TMMD) Program to 101 year of 2018 improves social resilience of the community :-

Indonesian National Army (TNI) United In Building Village (TMMD) is a TNI program in assisting government programs to accelerate development in the region as well as for equitable development in Indonesia and improve the welfare of the people in the region Policy. of Indonesian National Army (TNI) United In Building Village (TMMD) is a part of territorial development that is carried out to empower the land in defense on land and its supporting forces early in accordance with the defense system of the universe and to realize the unity of the TNI-People. In order for the organization of the of Indonesian National Army (TNI) United In Building Village (TMMD) to be able to succeed optimally, a policy is needed through the development of collaboration between relevant agencies and the community.

The aim is to create mutual understanding among relevant agencies about the duties, functions and roles of the Army, especially the Satkowil in the implementation of Binter and to create relations and cooperation and a good and integrated coordination mechanism between the Army and related agencies and the community. Positive Impact of TMMD activities is Soldiers must really understand the actual problems that are developing in the community, so that the similarity of attitudes and actions will be obtained that are in line with the characteristics of the area of duty. Such knowledge and insights must be possessed by Regional Command officials, especially in the face of rapid and dynamic environmental changes, which will directly or indirectly come into contact with the interests of carrying out their duties as territorial apparatus. Significantly, TMMD has succeeded in building facilities and infrastructure in the economic, socio-cultural, defense and security fields that provide direct benefits to people's lives.

According to Sergeant Sutrisno, it was agreed that Ops TMMD stated that the objective of the mechanism and management of TMMD activities was integrated between functional institutions in the management of regional resources in order to improve the welfare of the people in the regions. As well as the realization of the understanding of the Regional Government and related institutions on the binter function carried out by the Army.

Subjects; to foster collaboration between relevant agencies in order to create optimal results from TMMD activities in order to improve the welfare of the people in the area, the subjects are the Dandim and Danramil. In the implementation of cooperation development activities carried out with coordination, communication and collaboration with relevant agencies of the same level.

Object; In the development of cooperation between related institutions and status as partners are Regency and City level Regional Governments, Regency and City level DPRDs, Indonesian Police level Regional Offices, Resort Police and Sectors Police and Offices or other related Agencies that have duties and authorities in empowering the region for the welfare of the community.

Method; What can be used include Counseling, is a form of communication activity that aims to provide understanding or transfer of knowledge that can be done formally or non-formally. Coaching, is a form of communication activity that aims to provide positive supervision and control that is carried out continuously and continuously so that it works. Joint activities, are forms of communication activities aimed at developing collaboration with relevant agencies and the community. Infrastructure facilities are as follows: physical development (economic, social and cultural); non-physical development (state defense and skills).

Obstacles to Optimization and Implementation of the Indonesian National Army (TNI) United In Building Village (TMMD)Program to 101 Year of 2018:-

The limited capacity of the government, especially the regional government, which is currently uneven as a result of the implementation of regional autonomy, there are those who are able to both from Natural Resources and Human Resources, but there are regions that are not yet capable and still very dependent on the central government. The overall economic factor of the nation is an important factor in supporting development success in addition to other factors that are not less important. For success in carrying out development in all fields of life, several criteria are needed that can support this success. Similarly, in the implementation of Indonesian National Army (TNI) United In 
Building Village (TMMD) as one of the activities to improve development is influenced by several factors both from (internal) and external (external).

Table 3.1:-Internal and external factors that influence TMMD activities

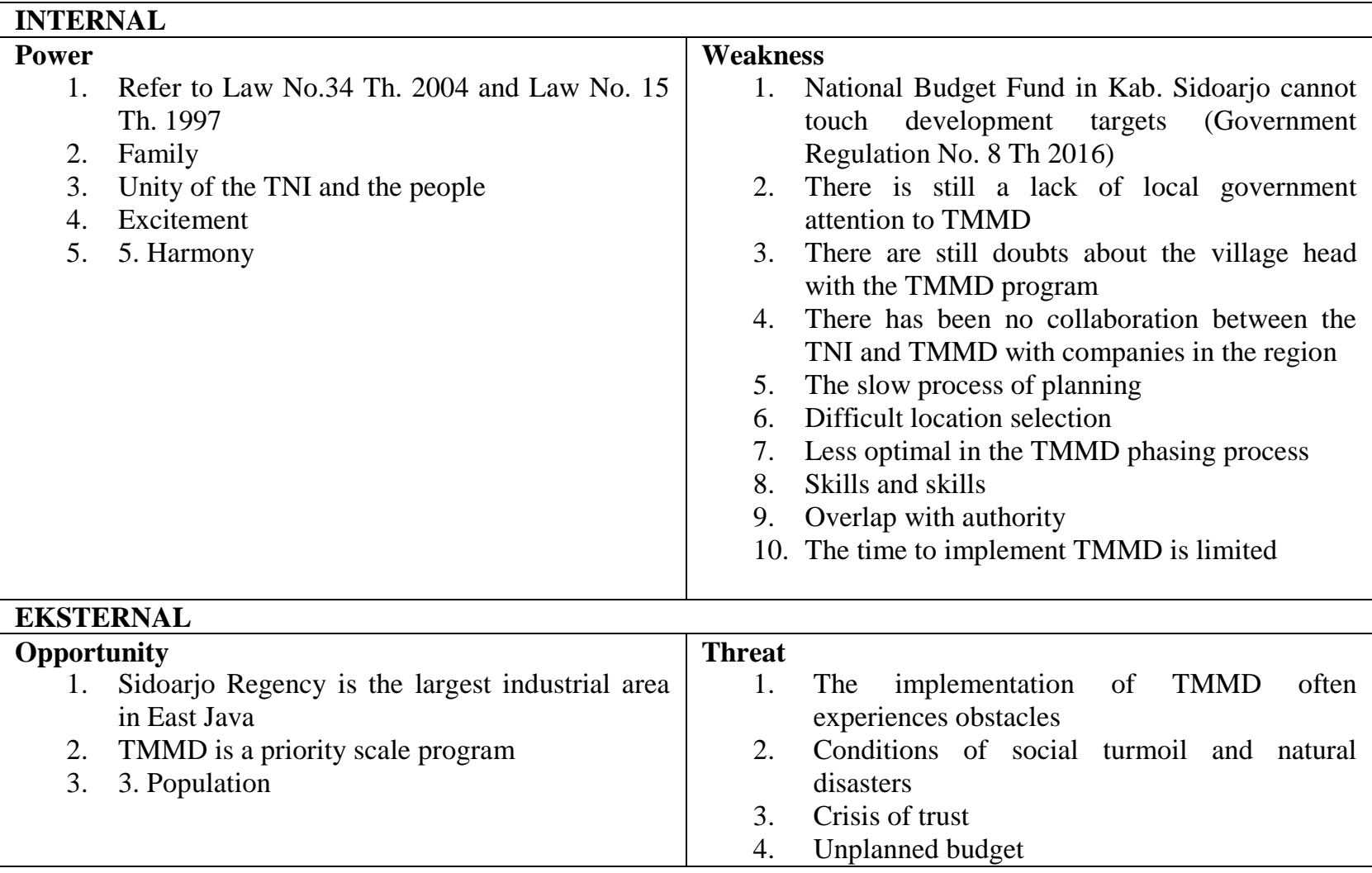

Model of Optimization and Implementation of Indonesian National Army (TNI) United In Building Village (TMMD) Program to 101 year of 2018 which is effective and efficient :-

Improving the welfare of the people in the regions must be a priority of the government and one of the efforts to improve welfare is through optimizing the implementation of Indonesian National Army (TNI) United In Building Village (TMMD)

\section{Planning phase.}

1. Determination of the program. In the current reform era where the government system shifted from centralization to decentralization meant the enactment of Regional Autonomy. With regional autonomy, the determination of Indonesian National Army (TNI) United In Building Village (TMMD) program can be determined earlier so that it is expected that the implementation of activities can achieve the desired goals.

2. Coordination. Coordination can be carried out at the lower level does not have to wait for a decision from above. Carrying out coordination before carrying out an activity is very important because with integrated coordination an activity can run smoothly. Likewise the Village has been given its own authority in managing the Village budget sourced from both the APBD and from ABPN.

3. Meetings. In escorting the target TMMD must be emphasized to 1 (one) part of the head of the particular SKPD field, and not to be changed, so that in the implementation of the coordination meeting, the TMMD program can be followed up to completion.

4. Make an initial plan. After the coordination is carried out properly, start an initial plan including determining the possible targets. In the stage of determining the Indonesian National Army (TNI) United In Building Village (TMMD) target plan to build a village, this needs to involve various elements of the community, with the intention of the government to be able to input which goals need to be prioritized.

5. Field / Survey review. After determining the interim target to ensure that the target of Indonesian National Army (TNI) United In Building Village (TMMD) needs to be carried out a field review / survey in the field. At 
the time of conducting the survey, it is necessary to involve the agency or department that is owned by the region, which of course has people who are experts in their respective fields.

6. Partnership. In the implementation of TMMD it should also involve elements from regional companies or banks, as well as institutions outside the government to participate in building the village through the TMMD program by utilizing the CSR budget support of a company. So that it can connect cooperation between the company and the TNI.

7. Budgeting system. This TMMD program should be easier to use the Grant from the Regional Government both on physical and non-physical targets so that it is expected that the TMMD Task Force can freely use the budget in accelerating the TMMD program, but this is difficult to do by the Kodim because the Kodim is not a Satker but the Implementation Unit below Korem, so Korem as Kasatker. With this, an easy solution can be found, namely by using the Self-Management system. Self-Management itself was according to Presidential Regulation Number 54 of 2010 concerning self-management explained that in point article 27 between selfmanagement is divided into 3 (three) parts, namely self-management by the guards themselves (in this case the local government), self-management involving community organizations and self-management carried out by government agencies. In this case the Kodim can do TMMD work using a self-management system carried out by government agencies, so that the TMMD in the future can be implemented absolutely by the Kodim and not necessarily with the contractualization system.

8. Completion of the plan in improving this plan all parties must be involved both from the TNI and from the local government. And from the SKPD in charge of Physical and non-physical targets, it is reasserted that the TMMD target has actually entered Renja and RKA, thus avoiding changes in budget support from the APBD.

9. Exposure. At the time the presentation should be carried out by the second level regional government (two) accompanied by the Kodim in this case the Regent together with the Dandim explained all plans to the Local Government of the level 1 (one) and Danrem with the expectations of the Command of each agency both TNI and Regional Government (one) can find out all the lower Command plans, also can be known obstacles and obstacles faced.

10. The auction process. With the existence of Presidential Regulation number 16 of 2018 concerning the procurement of government goods and services, projects worth more than 1 billion must be done through public tenders / tenders, in this case the authority of the Regional Government of Sidoarjo's ULP must quickly auction the physical target of TMMD by estimating the time so that in the implementation TMMD does not occur, considering the period of TMMD must be jammed within 30 days.

11. Socialization. Before the implementation of the Pre TMMD, it is better if the Regional Government or Kodim conducts a socialization on the implementation of TMMD to all Village Devices, BPBD, Chairperson of the RW, RT head and other community representatives explained about the purpose and objectives of TMMD, so that later when the community mobilization TMMD is implemented to participate in building the TMMD development, it can be deployed optimally and effectively.

\section{Preparation phase.}

1. Pre TMMD. Pre Indonesian National Army (TNI) United In Building Village (TMMD) activities are carried out with the aim of working on a fairly heavy work or target which is usually expected not to be completed during the Indonesian National Army (TNI) United In Building Village (TMMD) The local government can fully support both the preparation of the facilities and infrastructure needed and the deployment of workers who can support the implementation of activities.

2. Preparation of Facilities and Infrastructure.

1. Preparation of equipment.

2. Site Preparation.

3. Preparation of workforce

\section{Implementation Phase.}

1. Physical Development. During of Indonesian National Army (TNI) United In Building Village (TMMD) Activities, government officials must be willing to go to the field to see the development activities carried out by the TNI and the people.

2. Non-Physical Development. The target of non-physical development which is the target of Indonesian National Army (TNI) United In Building Village (TMMD) focuses more on the activities of how to build human resources so that they can advance to advance themselves. Non-physical development is carried out through activities using methods including: 
1. Guidance / Counseling.

2. Guidance / coaching.

3. Training.

4. Example / role model.

5. Provision of Assistance.

6. Social Service Assistance.

7. Task Force.

8. Publication.

9. Joint Watching Activities.

\section{Termination Phase.}

The end result of TMMD must truly be of benefit to the community at large by putting forward the Bakti TNI method as one of Binter's methods is the involvement of the TNI as the main component of national defense in assisting the implementation of humanitarian activities to deal with social and humanitarian issues at the request of relevant agencies and or own initiatives carried out jointly with relevant agencies and communities without neglecting unit readiness.

\section{Analysis of the results of activities:-}

By paying attention to the results achieved in the Indonesian National Army (TNI) United In Building Village (TMMD) program in 2018 and the main problems faced and the policies of the Indonesian National Army (TNI) United In Building Village (TMMD) can lead to an analysis, among others, as follows:

\section{Implementation aspects.}

1. Planning aspects. The arrangement of products for the Indonesian National Army (TNI) United In Building Village (TMMD) Activity to 101 Year of 2018 and the implementation of coordination efforts with related institutions in the region with the realization of cooperative efforts in organizing the Indonesian National Army (TNI) United In Building Village (TMMD) to 101 Year of 2018 in Penatarsewu Village, Kec. Tanggulangin Kab. Sidoarjo.

2. Preparation aspect. The implementation of communication and coordination mechanism among TNI units in this case the District Military Command 0816 Sidoarjo and the TMMD SSK Forces, the Sidoarjo Regency Government, the Pull District and the related Agencies, Tomas and other community component elements both at the central and regional levels.

3. Implementation aspects. The realization of space, tools and conditions of struggle and the unity of the military the people and the establishment of a positive image of the existence of TNI units in the area.

4. Termination Aspect. Availability of data / reports on the results of activities in the Indonesian National Army (TNI) United In Building Village (TMMD) to 101 Year of 2018.

\section{Aspects of achieving Binter goals.}

1. Judging from the Fighting Room. The more even distribution of development and the improvement of people's welfare.

2. Judging from the Fighting Tool. The increasing nationality, orderly law and national discipline and the increasing awareness of the people, nation and state.

3. Judging from the Conditions of Fighting. The awareness of the public in defending the country is reflected in the attitude of every citizen in accordance with their respective fields of profession or service.

4. Judging from the Unity of TNI - Rakyat. The growing sense of togetherness and family, national unity and unity.

Aspects of local government and community support. Grow and develop a perspective between government officials and community development in an integrated and institutionalized way in fostering communities and the environment which is reflected in the increasingly integrated cross-regional programs in developing rural areas.

Aspects of operational budget support from the Regional Government. The budget / cost for the development of both physical and non-physical activities is charged by the District Government. Sidoarjo through the APBD TA budget. 2016 in accordance with the letter of the Minister of Home Affairs of the Republic of Indonesia Number 900/2677 / SJ dated November 8, 2007, including support for the implementation of TMMD activities and regional assistance including the TMMD program. 
Efforts and Strategies for Optimizing and Implementing the TMMD Program:-

1. Strengthening the TMMD Program on a priority scale through broader legal certainty as a regulation of relations between interested institutions / state institutions.

2. Integrating Local Government Programs, Villages into the TMMD Program more specifically.

3. Seeking change in mindset / mindset of the community towards the TMMD Program.

4. Optimal utilization of regional resources.

5. The use of social media as a prestigious event in the optimization of the TMMD program.

\section{Conclusions And Suggestions:-}

\section{Conclusions:-}

Based on the description above, the writer can draw the following conclusions:

Optimization and implementation of the Indonesian National Army (TNI) United In Building Village (TMMD) program to 101 Year of 2018 in order to improve the social resilience of the community carried out by Kodim 0816 Sidoarjo together with the Sidoarjo Regency Government, it is necessary to optimally require a policy to start the development of collaboration between agencies starting from the objectives, targets, subjects, objects, methods ranging from physical development, economic, socio-cultural, non-development physically carried out through increasing awareness of state defense, community skills, entrepreneur debriefing, social culture, education and legal literacy.

In the face of various obstacles to the optimization and implementation of Indonesian National Army (TNI) United In Building Village (TMMD) program to 101 Year of 2018, as one of the activities to improve development is influenced by several factors both from (internal) and external (external). starting from internal factors that are seen from the strengths and weaknesses, while external factors can be seen from opportunities and threats. the most important thing is how to manage the APBD budget to support activities in total to the TMMD program as a special budget allocation, so that what is proposed by the village in proposing the TMMD budget is no longer constrained by the delimitation authority between the APBD and APBDes and the realization of integrated mechanisms and management of TMMD activities between functional institutions in the management of regional resources enhance the welfare of the community;

The optimization and implementation model of Indonesian National Army (TNI) United In Building Village (TMMD) implementation program must be well planned, starting from the planning, preparation, implementation and scaling up stages so that the target can touch the needs of the community and in accordance with the priority scale of needs. Improving community welfare must be a benchmark for the success of the Indonesian National Army (TNI) United In Building Village (TMMD).

\section{Suggestion:-}

From the conclusion of this paper a number of suggestions can be put forward as a reference for the future in carrying out the activities of Indonesian National Army (TNI) United In Building Village (TMMD), as follows:

\section{Government.}

The central government needs to provide strong laws in support of future TMMD activities so that in the future TMMD targets can be implemented with priority scales without having to clash with other rules in the process of making accountability.

The Regional Government, it is necessary for TMMD in the future to be able to sit together between the Regional Government and the Village Apparatus to discuss about the synchronization of the APBD and ABPDes budget can be used in supporting TMMD activities, so that there are no obstacles back about the rights and authority of APBD and APBDes budget usage;

Kodim 0816 Sidoarjo organizer

In the event the coordination activities are more intensified so that the implementation of TMMD can be implemented in an integrated manner between the TNI, Village Government, relevant agencies and the community so as to achieve optimal results and so that the fulfillment of materials and equipment can be fulfilled early so that in 
the implementation of TMMD in particular the physical development of time and target what has been determined can be achieved maximally; and

The organizers are expected to continue to evaluate, both at the internal level of the body of the army itself and evaluation of the community, village officials and agencies that become partners, by asking for criticism and advice to all parties involved in the shortage of this program so that in the future it becomes material for correction. Another suggestion is to continuously improve the quality of program management and add activities, especially non-physical activities such as community empowerment and social development.

\section{Village and Community Apparatus.}

The Penatarsewu Village apparatus should provide routine guidance and monitoring of social changes that occur in the community at the RT / RW level of the BPD after the TMMD program. In addition, another suggestion is to continue to improve community services, especially aspirations for the analysis of community needs both in the field of physical development and non-physical development, and by continuing to submit proposals in the form of development and development programs to various agencies and sponsors to be able to capture partners who can help advance and develop Penatrsewu Village.

Penatrsewu Village Communities are expected to continue to maintain and maintain development products, such as physical development products such as roads, Irrigation Development, schools, Clean Water and non-physical development such as utilization of waste management equipment, fish seed assistance, socialization of the dangers of drugs, socialization of state defense awareness and an orderly legal culture. After this TMMD program, the community is expected to be able to take advantage of the positive results of this program such as good road access to be able to be used as a business opportunity that can improve the marketing of agricultural and fishery products and be able to create jobs through SME (small and medium enterprises) products.

\section{For future researchers.}

The learning process here that needs to be considered by future researchers is the factor that supports the TMMD program is the readiness, alertness and discipline of the organizers in planning, implementing and evaluating the entire series of activities in the TMMD program arrangement. In addition, the cooperation of various parties involved has supported the smooth process of completing the program. The people involved as TMMD program users have an open attitude in every change offered. The opportunity that arises from this program is the potential of human resources in the village community which is very good, especially in terms of work ethic. Another opportunity is the inter-sectoral partnership that can be developed by TMMD organizers, namely the 0816 Kodim Sidoarjo to continue to embrace parties from other agencies so that they can cooperate in the future, and can be used as a reference in future research.

\section{Bibliography:-}

1. Bujuknik tentang Bhakti TNI Skep/147/V/2002 tanggal 31 Mei 2002 tentang pedoman pelaksanaan TNI Manunggal Membangun Desa (TMMD).

2. Buku Pedoman Tentang Penyelenggaraan TMMD Jakarta April 202.

3. Peraturan Menteri Pertahanan Republik Indonesia nomor 40 tahun 2011 tentang Pertahanan Negara.

4. Peraturan Presiden RI Nomor 16 Tahun 2018 tentang Pengadaan Barang/Jasa Pemerintah.

5. Sari, K. 2012. Ketahanan Nasional (konsep dan teori) I himpunan lemhanan 1980. PT Ripres Utama. Jakarta. 